\title{
Advanced Treatment of Waste Water Using Microalgae In and Around the region of Gengavalli
}

\section{Dr. P. Vijaya Kumar, Dr. S. Ananthakrishnan*,}

\author{
${ }^{1}$ Department of Chemistry,Jairam College of Arts and Science, Affiliated to Bharathidasan University, Karur-639003. \\ ${ }^{2 *}$ Department of Chemistry, Rover Engineering College, Affiliated to Anna University, Perambalur-621 212,Tamilnadu, India.
}

\begin{abstract}
The present study illustrates the efficiency of microalgae based treatment system. Treatment of wastewater with microalgae based system have the ability of remove the nutrients( nitrogen , phosphorus and other nutrients ), heavy metals ,toxic substance (both organic and inorganic), BOD ,COD and other impurities present in the waste water by using the sunlight, $\mathrm{co}_{2}$ and impurities like nutrients present in the wastewater. The microalgae also have the ability of the fix the excess carbon dioxide present in the environment and release the oxygen and solve the problem of global warming .According to the various study the nutrients removal efficiency of $78-99 \%$ of nitrogen and phosphorus the treatment system also succeed to removal of the 40-65\% of COD , BOD and other impurities present in wastewater. The organic and inorganic substance released into the environment as a result of domestic, agricultural and industrial wastewater. The normal primary \& secondary treatment process are involved in the treatment. Present investigation focuses on the bioremediation of waste water using microalgae.
\end{abstract}

*Corresponding Author E-mail: ananthajmc2011@yahoo.com

Keyword: COD,BOD, Microalgae, waste water treatment. 


\section{INTRODUCTION}

Microalgae based wastewater treatment system with are as effective as conventional wastewater treatment system. Cultivation of microalgae in wastewater for waste water treatment. Pollution control and production of energy from microbial is nowadays common treatment method. Microalgae based treatment system is one of a good solution to solving the environmental problems such as global warming the increase of ozone hole and climate changed due to is a ability to consume high quantity of carbon dioxide in photosynthesis process to produce and glucose. Microalgae have the ability to remove nutrients heavy metals. Organic and inorganic toxic substances and other impurities present in the wastewater by other metals. The released oxygen from microalgae is enough to meet the most aerobic bacterial requirements while metabolizing the residual organics in the treated waste water. Bioremediation of uses naturally occurring microorganisms and other aspects of the natural environment to treat waste water and its nutrients.

\section{waste water treatment in microalgae}

Microalgae offers an interesting step for waste water treatment because they provide a tertiary bio treatment coupled with the production of potentially valuable biomass which can be used for several purposes. Their capacity to remove heavy metals, as well as some toxic organic compounds therefore it does not leads to secondary pollution. Which are important to the design and operation of high rate algal cultures to produce high value products such as pharmaceuticals and genetically engineered products. the land space requirements of micro algal waste water treatment systems are substantial efforts are being made to develop waste water treatment system. This system proved to be highly efficient in removing of $\mathrm{N}$ and $\mathrm{P}$ within very short periods of time e.g, less then 1 hour. Algae based system for the removal of toxic minerals such as lead cadmium mercury, tin arsenic, bromine are also being developed. Waste water treatment system using microalgae represent a low cost and environment friendly waste water treatment alternative when compared to conventional waste water treatment process. For example integrated algal waste water treatment system are able to capture $\mathrm{CO}_{2}$ from power plants and remove nitrogen and phosphorus from waste water.

\section{SEWAGE TREATMENT PROCESS}

waste water treatment process is following

- conventional treatment process

- Preliminary treatment process

- primary treatment process

- tertiary treatment process

\section{conventional treatment process}

In waste water treatment system is removal of BOD, suspended solids, nutrients, bacteria, and toxicity are the main goal for getting purified waste water. Bod exploits the ability of 
microorganisms to oxidize organic material to $\mathrm{Co}_{2}$ and water using molecule oxygen as an oxidizing agent. Discharge these nutrients into sensitive water bodies leads to eutrophication by stimulating the growth of unwanted plants such as algae and aquatic macrophytes. Suspended solids are removed principally by physical sedimentation. Other consequence of nitrogen compounds into waste water effluents are toxicity of non ionised ammonia to fish and other aquatic organisms, interference with disinfection where a free chlorine residual is required and non methamoglobinemia in influents due to excessive nitrate concentration $45 \mathrm{~g} / \mathrm{m}^{3}$ in drinking water.

\section{Preliminary treatment}

In these process removal of coars materials, which aims to removal of settable solids by gravity. A well designed sedimentation tank can remove $40 \%$ of the bod in the form of settable solids. Pathogen removal during primary treatment is highly varied with various removal rates. The preliminary treatment of sewage removes large solid materials delivered by sewers that could obstruct flow through the plant or damage equipment. These materials are composed of floating objects such as rags, wood, fecal materials and heavier grit particles. Large floating objects can be removed by passing the sewage through bars spaced at $20-60 \mathrm{~mm}$ the retained materials are raked from the bars at regular intervals. Grit is removed by reducing the flow velocity to a range at which grit and silt will settle but leave organic matter in suspension this is usually in the velocity range of $0.2-0.4 \mathrm{~m} / \mathrm{s}$.

\section{Primary treatment}

In these process aims to reduce the BOD exerted by reducing the organic matter. A large number of biological unit are available to achieve the aerobic oxidation of BOD. In suspended growth reactors the microorganisms mix freely with the waste water and are kept in suspension by mechanical agitation or mixing by air diffusers. Several investigators have pointed out that biological oxidation can remove over $90 \%$ of pathogenic bacteria from waste, the removal of viruses is much more varied. After removal of the coarse materials, sewage passes to sedimentation tanks which aim to remove the settle able solids (represent up to $75 \%$ of the total settle able solids) by gravity. A well designed sedimentation tank can remove $25 \%$ of the BOD in the form of settle able solids. Pathogens removal in primary treatment is highly varied with various rates reported for different organisms

\section{Tertiary treatment}

The treatment aims to remove all organic ions.it can be accomplished by biologically or chemically. Removing of ammonium nitrate and phosphate is estimated to be 4 times more expensive in primary treatment. Advanced treatments are generally based on technologically complex techniques such as chemical precipitation, ozonation, reverse osmosis. Some industrial, agricultural waste water show total N, P concentration up to 3 orders of magnitude higher then natural water bodies. Complete tertiary process aimed at removing ammonium nitrate and phosphate is estimated to be about four times 
more expensive than primary treatment .quaternary treatment intended for the removal of heavy metals,organic compounds and soluble minerals will be about eight to sixteen times more expensive than primary treatment. some industrial and agricultural waste water show total nitrogen and phosphorus concentrates up to three orders of magnitude higher than natural water bodies the normal and primary and secondary treatment process have been introduced in a growing number of places, In order to eliminate the easily settled materials.

\section{Dis inspection of waste water:}

Primary, secondary and even tertiary treatment process cannot by excepted to remove $100 \%$ of the incoming waste load and as a result many organisms will remain in the waste stream to prevent the spread of waterborne diseases and also to minimize the public health problems, regulatory agencies may require the destruction of pathogenic organisms in waste water. The reduction of bacterial numbers to minimize health hazard is a very desirable goal. Dis inspection is the treatment of the effluent for the destruction of all pathogens. Destruction of microorganisms is sterilization. It is the destruction of all microorganisms. While disinspection indicates the destruction of all diseases causing microorganisms. In general dis inspection can be achieved by any method that destroys pathogens. A variety of physical, chemical methods are

Reduction of both chemical and biological oxygen demand capable of destroying microorganisms under certain conditions. However the treatment of waste water for the destruction of pathogens demands the use of practical measures that can be used economically and efficiently at all times on large quantities of waste water have been treated to various degrees. In the past waste water treatment practices have practically relieved on the use of chlorine for dis inspection.

\section{Removal of coliform bacteria}

For algal growth unfavourable for the survival for the coliforms. Pathogenic organisms of concern in waste water include bacteria such as salmonella and shigella, viruses and protozoa. Bacteria provide the largest component of the microbial community in all biological waste water treatment process and numbers in the range of $10^{6}$ bacteria/ml of waste water are frequently encountered. Experimental evidences indicate that the pathogenic bacteria generally have shorter survival in the times in the environment then coliforms whereas viruses tend to survive longer. The efficiency of sewage is estimated by the extent of removal of total coliforms organisms. Considerable coliforms is removed is achieved by the stabilization ponds. In these respect sewage stabilization ponds are high rate sewage stabilization ponds are well known for being generally more effective then conventional treatment system.

There are many compounds and microorganisms could be detected in waste water. Which is capable of causing the pollution of a 
waste course Pollution of waste water may be manifested in three broad categories namely organic materials, in organic materials in addition to microbial contents. These carbon atom may be oxidized both chemically and biologically to yield carbon di oxide. The carbon atoms may be oxidized both chemically and biologically to yield carbon di oxide. If these biological oxidation is employed the test is termed the BOD where the chemical oxidation the test is termed as COD, In other words BOD exploits the ability of microorganisms.to oxidise organic material to carbon di oxide and water using molecular oxygen as an oxidizing agent. The bod is a measure of the respiratory demand of bacteria metabolising the organic matter present in the waste water. They found that in domestic waste water treatment elimination of cod and bod were $25 \%$. Respectively.

\section{Removal of $\mathbf{N}$ and $\mathbf{P}$}

The nitrogen in sewage effluent arises primarily from metabolic in inter conversions of extra derived compounds whereas $50 \%$ or more $\mathrm{P}$ arises from synthetic detergents. Waste water is mainly treated by aerobic or biological degradation. The treated water still contains inorganic compounds such as nitrate, ammonium and phosphate ions which lead to eutrophication in lakes and cause harmful micro algal blooms. The ability of algae to remove $\mathrm{N}$ and $\mathrm{P}$ Simultaneously. While $\mathrm{N}$ removal by microalgae public concern This can be depend on the algae, the metal ion species the solution condition and their the algal cells are living or nonliving. In is believed to be the result of assimilation. $\mathrm{P}$ Removal by microalgae is still not as well understood and 2 metabolic processes for $\mathrm{P}$ removal have been still debated.. Other microorganisms in waste water can out complete the algae for essential nutrients and pathogenic bacteria or predatory zooplankton will harm the microalgae. Micro algal culture offers a cost effective approach to removing nutrients from waste water. Micro algal culture offers an elegant solution to tertiary and quaternary treatments due to the ability of microalgae to use inorganic nitrogen and phosphorus for their growth and their capacity to remove heavy metals.

\section{Heavy metals removals in waste water.}

Microalgae are known to sequester heavy metals. Discharge of toxic pollutants to waste water collection system has increased concurrently with society progressive industrialization. Microalgae are efficient absorbers for heavy metals. Bioaccumulation of metals by algae creates a feasible method for remediating waste water contaminated with metals. Although the heavy metals contents in some drainage systems generally do not reach the proportions found in industrial effluents certainly not those of metal processing industries effluents certainly not those of metal processing industries the problems caused by their presence particularly in areas with dense population are of

living algal cell that trace nutrient metal such as (co, mg, ca, mg, cu, zn, cr pb and sn ) are accumulated intracellular by active biological 
Jamal Academic Research Journal-an Interdisciplinary

P. Vijaya Kumar et al JARJ-Vol-1-1-FEB-2020:6-12

transport. Field experiments indicate that live Cadmium was absorbed little less efficiently with photosynthetic microalgae have an effective role in metal detoxification of mine waste water. about $60 \%$ of the cadmium being absorbed from a $40 \mathrm{ppb}$ solution after $24 \mathrm{~h}$.

\begin{tabular}{|c|c|c|c|c|c|}
\hline & Name of parameter & \multicolumn{4}{|c|}{ Sample details } \\
\hline 1 & & 1 & 2 & 3 & 4 \\
\hline \multicolumn{6}{|c|}{ Physical parameter } \\
\hline 1 & Color & $>1$ & $>1$ & $>1$ & $>1$ \\
\hline 2 & Odor & unpleasant & Unpleasant & unpleasant & Unpleasant \\
\hline 3 & Turbidity & $15 \mathrm{NTU}$ & $15 \mathrm{NTU}$ & $20 \mathrm{NTU}$ & $25 \mathrm{NTU}$ \\
\hline 4 & TDS & 608 & 557 & 682 & 794 \\
\hline 5 & $\mathrm{PH}$ & 7.69 & 7.98 & 8.10 & 8.20 \\
\hline 6 & $\begin{array}{l}\text { Electrical } \\
\text { conductivity }\end{array}$ & 0.95 & 0.87 & 1.06 & 1.26 \\
\hline 7 & BOD & 185 & 175 & 182 & 176 \\
\hline 8 & COD & 56 & 57 & 62 & 64 \\
\hline \multicolumn{6}{|c|}{ Anions } \\
\hline 9 & Carbonate & NIL & NIL & 0.52 & 0.62 \\
\hline 10 & Bi carbonate & 256 & 248 & 262 & 216 \\
\hline 11 & chloride & 189 & 178 & 196 & 187 \\
\hline 12 & Sulphate & 89 & 97 & 96 & 95 \\
\hline 13 & phosphate & 0.06 & 0.02 & 0.03 & 0.05 \\
\hline 14 & silicate & 4.26 & 4.59 & 4.68 & 5.06 \\
\hline 15 & nitrate & 0.23 & 0.21 & 0.21 & 0.25 \\
\hline 16 & nitrite & NIL & NIL & NIL & NIL \\
\hline 17 & Flouride & 5.69 & 5.21 & 5.42 & 5.48 \\
\hline 18 & aluminum & NIL & NIL & NIL & NIL \\
\hline \multicolumn{6}{|c|}{ Cations } \\
\hline 19 & calcium & 250 & 219 & 236 & 259 \\
\hline 20 & magnesium & 126 & 124 & 136 & 135 \\
\hline 21 & sodium & 65 & 69 & 54 & 59 \\
\hline 22 & potassium & 0.13 & 0.18 & 0.16 & 0.19 \\
\hline \multicolumn{6}{|c|}{ Heavy metals } \\
\hline 23 & Zinc & 0.06 & 0.03 & 0.02 & 0.06 \\
\hline 24 & copper & 0.01 & 0.01 & 0.02 & 0.02 \\
\hline 25 & Iron & 0.05 & 0.06 & 0.05 & 0.04 \\
\hline 26 & manganese & 0.02 & 0.02 & 0.2 & 0.02 \\
\hline 27 & chromium & NIL & NIL & Nil & Nil \\
\hline 28 & lead & Nil & Nil & Nil & Nil \\
\hline
\end{tabular}

\section{Algae as monitor of water quality.}

During the last three decades several investigations have described the algal bioassays in response to environmental perturbations and their use of indicative organisms of water quality. Which could be used as indicators of water pollution whereas the presence of different 
organisms such as lamenea and certain species of micrastrerias meridian, pinnularia, would indicates that the water sample would be considered unpolluted.

\section{Chlorella}

Family : chlorellaceae

Genus : chlorella; M. Beijerink, 1890

Phylum: chlorophyta

Class : trebouxiophyceae

Shape : spherical

Chlorella, genus of green algae fount their singly or clustered in fresh or salt water and in soil. Chlorella has been extensively in photosynthetic studies in mass cultivation experiments, and for purifying sewage effluents. Because the algae multiply rapidly and are rich in proteins and $\mathrm{B}$ complex vitamins. Several species have also been studied as a potential food product.

The algal cell is roughly spherical and features a cup shaped chloroplast and numerous starch grains member of genes reproduce asexually by nonmotal reproductive cells that rupture through the mother cell. Those cells sometimes cling together to form a colony. Chlorella is a genus of single celled green algae belonging to the division of chlorophyta. Chlorella can serve as a potential source of food and energy because its photosynthetic

\begin{tabular}{|c|c|c|c|c|c|c|c|}
\hline ALGAE & SOLVENT & \multicolumn{6}{|c|}{$\begin{array}{c}\text { ACTIVITY AGAIN } \\
\text { PATHOGENS } \\
\text { E.coli K.pnemonia S paratyphi } \\
\text { P.flouroscenece }\end{array}$} \\
\hline \multirow{8}{*}{ Chlorella } & ACETONE & - & - & - & + & - & + \\
\hline & Cold water & + & - & - & - & + & - \\
\hline & Dichromethane & _- & - & + & + & - & - \\
\hline & Diethyle & - & + & - & + & - & - \\
\hline & Ethanol & + & - & - & + & + & - \\
\hline & Hot water & - & - & - & - & - & _- \\
\hline & Methanol & - & - & + & + & - & - \\
\hline & Hexcane & - & - & - & - & - & - \\
\hline
\end{tabular}

\section{Conclusion}

Algae used in waste water treatment for a range of purpose, including, reduction of bod, removal of N, P, Inhibition of coliforms and removal of heavy metals. The high concentration of $\mathrm{N}, \mathrm{P}$ in most waste waters also means these waste water may possibly be used as cheap nutrient sources for algal biomass production. 
Despite at lengthy list of benefits full scale implementation of algae as a bioenergy source has been prohibitively expensive till date, especially when cultivated using artificial media. Advancement in microbiology chemistry and environmental engineering combined with additional funding and research should allow for rapid commercialization of this new biofuel and waste water treatment technology. Although there is much more to be discovered current literature supports algae as a promising biofuel source and effective waste water treatment strategy.

\section{References}

1. Borowitzka, M.A (2013). High value products from microalgae their development and commercialization. J.Appl. phycol 25,743.

2. Buckwalter, p. Empaye, t., gormly, s., and trent, J,D,(2013) dewatering microalgae by forward osmosis. Desalination 312, 19.
3. Campbell, P.K., beer. T., and batten, D. (2011) life cycle assessment of biodiesel production from microalgae in ponds. Bioresour, technol. 102,50.

4. Chisti, Y, (2007) biodiesel from microalgae. Bioethanol, adv. 25,294

5. Davis, R., Aden, A., and pienkos, P.T. (2011). Techono economic analysis of autropic microalgae for fuel production. Appl, energy 88, 3524.

6. Edzwald, J, (1993) algae bubbles, coagulants and dissolved air flotation. Water sci, technol, 27,67

7. Ghirardi, M.L., Zhang, 1., lee, j.w., t., seibert, m., greenbaum, E., and melis, A. (2000) microalgae. A green source of renewable $\mathrm{h}_{2}$. Trends biotechnol 18,506.

8. Harun, R., And danquah, m.k (2011). Influence of acid pretreatment of microalgal biomass for bioethanol production. Process biochem. 46,304.

9. Hwang, J.H., Kabra , A,N., kim, J.R., and jeon B.H, (2014a) photohetropic microalgal hydrogen production using acetate and butyrate-rich waste water effluent, energy 78,887 